\title{
Informace o akcích pro vysokoškolské studenty, pedagogy a odbornou veřejnost
}

Centrum pro otázky životního prostředí UK

Envigogika 8 (5) Informace/Information

Publikováno/Published 31. 12. 2013

DOI: http://dx.doi.org/10.14712/18023061.424

\section{WORKSHOP: SVĚT PO ROCE 2015 - VZDĚLÁVÁNÍ K UDRŽITELNOSTI}

Dne 22. ledna 2014 se v prostorách Informačního Centra OSN v Praze uskuteční jednodenní praktický workshop pro pracovníky ve vzdělávání zaměřený na udržitelný rozvoj a globální agendu po roce 2015. V rámci workshopu účastníci získají aktuální informace o připravované agendě OSN, seznámí se s interaktivní vzdělávací aktivitou „Pyramida udržitelnosti" a budou mít možnost vyměnit si své zkušenosti v oblasti vzdělávání k udržitelnosti. Workshop organizuje Centrum pro otázky životního prostředí UK ve spolupráci s Informačním Centrem OSN v Praze. Všichni zájemci jsou srdečně vítáni!

Více informací a registrace: http://mosur.czp.cuni.cz/index.php/cz/udalosti/seminare/149prakticky-workshop-svet-po-roce-2015-vzdelavani-k-udrzitelnosti.

\section{WORKHOP: PSANÍ VĚDECKÝCH ČLÁNKŮ PRO PHD STUDENTY A POSTDOKY}

Ve dnech 17. a 19. února 2014 se uskuteční dva praktické workshopy pro mladé vědecké pracovníky (PhD studenty, postdoky) na téma psaní vědeckých článků. První proběhne na Jihočeské univerzitě v Českých Budějovicích, druhý pak na Univerzitě Karlově v Praze. Lektorem workshopu bude As. Prof. Rodrigo Lozano - asociovaný editor časopisu Journal of Cleaner Production (IF 3.398 za rok 2012), vydavatelství Elsevier. Jazykem workshopu bude angličtina.

Více informací a registrace: http://mosur.czp.cuni.cz/index.php/en/events/workshops/154editorial-workshops-on-writing-academic-articles-for-impact-journals

\section{WORKHOP: EDITORSKÝ PROCES V AKADEMICKÝCH ČASOPISECH}

Dne 18. února 2014 proběhne praktický workshop pro editory akademických časopisů a další odbornou veřejnost na téma editorského procesu $v$ akademických časopisech. Lektorem workshopu bude As. Prof. Rodrigo Lozano - asociovaný editor časopisu Journal of Cleaner Production (IF 3.398 za rok 2012), vydavatelství Elsevier. Jazykem workshopu bude angličtina. 
Více informací a registrace: http://mosur.czp.cuni.cz/index.php/en/events/workshops/154editorial-workshops-on-writing-academic-articles-for-impact-journals

\section{JARNÍ ŠKOLA: International Spring School on Sustainable Development 2014}

Centrum pro otázky životního prostředí Univerzity Karlovy v Praze zve studenty bakalářského či magisterského studia jakéhokoli studijního oboru k účasti na mezinárodní jarní škole s tématikou udržitelného rozvoje - International Spring School on Sustainable Development 2014. Kurz je pořádán ve spolupráci s několika evropskými VŠ institucemi a bude vyučován $v$ angličtině.

Kurz poběží v termínu 30. 3. - 5. 4. 2014 v Týnci nad Sázavou za 2 ECTS kredity.

Více informací a registrace: http://mosur.czp.cuni.cz/index.php/en/for-students/currentoffer/138-international-spring-school-on-sustainable-development-2014 